\title{
PENGARUH MODEL PEMBELAJARAN INKUIRI TERHADAP KEMAMPUAN BERPIKIR KRITIS
}

DAN HASIL BELAJAR SISWA KELAS IV SD PADA SUBTEMA KEINDAHAN ALAM NEGERIKU

\author{
Ari Wariyanti ${ }^{1}$, Rusijono ${ }^{2}$, Nasution ${ }^{3}$ \\ ${ }^{1}$ Mahasiswa Program Pascasarjana, Prodi Pendidikan Dasar, Universitas Negeri Surabaya, \\ ${ }^{2 \& 3}$ Dosen Pascasarjana, Prodi Pendidikan Dasar, Universitas Negeri Surabaya \\ e-mail: ari.wariyanti98@gmail.com
}

Received : Maret 2019

Reviewed : April 2019

Accepted : $\quad$ Mei 2019

Published : Mei 2019
ABSTRACT

This research aims to know the effect of inquiry learning model toward critical thinking skill and learning result of fourth grade student of Elementary School. The type of research is experiment research with form of research is pretest-posttest control group design. The research data was obtained as follows: the $t_{\text {test }}$ score $(13,539)>t_{\text {table }}(1,686)$ and mean score in experiment class is 91,2500 higher than the critical thinking skills of students in the control class 57,7083. So, there are effect of inquiry learning model toward student's critical thinking skill. As for the second hypothesis testing was shown with $t_{\text {test }}$ score $(4,459)>t_{\text {table }}(1,686)$ with mean score in experiment class is 87,5000 higher than student's learning results in control class 75,7500. So, there are effect of inquiry learning model to student's learning result. Based on the discussion of research results, it can be concluded that inquiry learning model has an effect to student's critical thinking skills and student's learning result in significant.

Keywords: Inquiry Learning Model, Critical Thinking Skills, Learning Result.

\section{ABSTRAK}

Penelitian ini bertujuan untuk mengetahui pengaruh model pembelajaran inkuiri terhadap kemampuan berpikir kritis dan hasil belajar siswa kelas IV SD. Jenis penelitian yang dilakukan adalah penelitian eksperimen dengan desain penelitian pretest-posttest control group design. Data hasil penelitian yang diperoleh sebagai berikut: nilai $t_{\text {hitung }}(13,539)>t_{\text {tabel }}(1,686)$ dan nilai mean pada kelas eksperimen sebesar 91,2500 lebih tinggi dibandingkan dengan kemampuan berpikir kritis siswa pada kelas kontrol yaitu sebesar 57,7083. Jadi, ada pengaruh model pembelajaran inkuiri terhadap kemampuan berpikir kritis siswa. Sedangkan untuk pengujian hipotesis kedua menunjukkan nilai $t_{\text {hitung }}(4,459)>t_{\text {tabel }}(1,686)$ dengan nilai mean pada kelas eksperimen sebesar 87,5000 lebih tinggi dibandingkan dengan hasil belajar siswa pada kelas kontrol yaitu 75,7500. Jadi, ada pengaruh model pembelajaran inkuiri terhadap hasil belajar siswa. Berdasarkan diskusi hasil penelitian, dapat disimpulkan bahwa model pembelajaran inkuiri berpengaruh terhadap kemampuan berpikir kritis siswa dan hasil belajar siswa secara signifikan.

Kata-kata Kunci: model pembelajaran inkuiri, kemampuan berpikir kritis, hasil belajar.

\section{PENDAHULUAN}

Pendidikan yang baik adalah pendidikan yang tidak hanya mempersiapkan para siswanya untuk sesuatu profesi atau jabatan, tetapi untuk menyelesaikan masalah-masalah yang di hadapinya dalam kehidupan sehari-hari (Trianto, 2010:4). Untuk menyelesaikan masalah tersebut, diperlukan suatu kemampuan berfikir. Berpikir terjadi dalam setiap aktivitas mental manusia berfungsi untuk memformulasikan atau menyelesaikan masalah, membuat keputusan serta mencari alasan. Salah satu kemampuan berpikir yang harus dikembangkan pada diri siswa adalah kemampuan berpikir kritis. Sebagaimana menurut Marzano (dalam Slavin, 2011: 37), salah satu tujuan utama bersekolah ialah meningkatkan kemampuan siswa berpikir 
kritis, agar dapat mengambil keputusan rasional tentang apa yang harus dilakukan atau apa yang harus diyakini. Kemampuan berpikir kritis ini perlu dilatihkan sejak dini pada siswa. Hal ini dikarenakan, berpikir kritis diperlukan dalam setiap profesi, dan itu memungkinkan seseorang untuk menghadapi kenyataan dengan cara yang wajar dan mandiri.

Namun demikian, dalam proses pembelajaran belum banyak guru yang menciptakan kondisi dan situasi yang memungkinkan siswa untuk berpikir kritis. Hal ini terlihat dalam kegiatan belajar mengajar guru menjelaskan materi yang telah disiapkan kemudian memberikan latihan soal yang bersifat hafalan materi.

Sebagaimana hasil observasi yang telah dilakukan di kelas IV di beberapa Sekolah Dasar di Kecamatan Tandes Surabaya, masalah yang timbul dalam pembelajaran antara lain, siswa mengalami kesulitan dalam memecahkan suatu masalah. Hal ini terlihat saat diberikan suatu permasalahan melalui kegiatan tanya jawab, siswa memberikan penyelesaian dengan informasi yang kurang lengkap, beberapa jawaban kurang logis dan penyusunan jawaban yang tidak sistematis. Bahkan ada beberapa jawaban yang tidak sesuai dengan permasalahan. Selain itu, dalam kegiatan pembelajaran di kelas, siswa kurang aktif bertanya dan mengungkapkan pendapatnya untuk menjawab pertanyaan sehingga guru perlu menunjuk siswa untuk memberikan jawaban mereka. Masalah lain yang timbul di kelas adalah kesulitan siswa memahami materi yang diajarkan. Hal ini ditunjukkan dengan rendahnya hasil belajar siswa.

Permasalahan tersebut disebabkan siswa jarang dilatihkan untuk berpikir kritis dalam menyelesaikan masalah, mereka tidak dilatihkan untuk melakukan penyelidikan terhadap suatu masalah, memahami asumsiasumsi, merumuskan dan menyeleksi hipotesis yang relevan, serta menarik kesimpulan yang valid berdasarkan penyelidikan. Biasanya mereka hanya belajar menghafal fakta atau informasi tertentu kemudian menjawab soal yang berkaitan dengan informasi tersebut tanpa menggunakan informasi tersebut untuk memecahkan masalah.

Untuk menyelesaikan masalah tersebut diperlukan suatu pembelajaran yang dapat melatihkan siswa untuk berpikir kritis dalam menemukan pemecahan permasalahan. Salah satunya yaitu menggunakan model pembelajaran inkuiri. Alasan penggunaan model pembelajaran ini adalah pembelajaran inkuiri menekankan pada proses berpikir secara kritis dan analitis untuk mencari dan menemukan sendiri jawaban dari suatu masalah yang dipertanyakan (Sanjaya, 2009: 196). Dengan menemukan sendiri penyelesaian dari suatu permasalahan, pemahaman siswa terhadap materi akan lebih kuat dan bermakna sehingga hasil belajar siswa dapat meningkat. Sebagaimana menurut Arends (2012: 341), model pembelajaran inkuiri merupakan model pembelajaran yang dikembangkan dengan tujuan mengajarkan siswa bagaimana cara berpikir. Sehingga dapat disimpulkan, pembelajaran inkuiri adalah pembelajaran yang melibatkan siswa secara aktif untuk mencari atau menyelidiki suatu benda atau suatu masalah secara sistematis, kritis, logis, analitis melalui berbagai macam sumber, sehingga mereka dapat menemukan sendiri penyelesaian dari suatu masalah.

Dalam sintak pembelelajaran inkuiri terdapat enam fase yang harus dilakukan, yaitu: (1) orientasi, (2) merumuskan masalah, (3) merumuskan hipotesis, (4) mengumpulkan data, (5) menguji hipotesis, dan (6) menarik kesimpulan.

Berpikir merupakan aktivitas mental yang dipengaruhi oleh keberadaan otak sebagai pusat kendali. Berpikir kritis mencakup kemampuan untuk menganalisis dan mengevaluasi proses berpikir itu sendiri. Menurut Surya (2011: 130), berpikir kritis diartikan sebagai sebuah proses aktif dan cara berpikir secara teratur atau sistematis untuk memahami informasi secara mendalam, sehingga membentuk sebuah keyakinan kebenaran informasi yang didapat atau pendapat yang disampaikan. Selanjutnya Jenifer (2011) menyatakan pentingnya berpikir kritis tidak bisa dianggap remeh karena fakta bahwa kritis dan informasi pengambilan keputusan adalah suatu kebutuhan ketika membuat keputusan yang akan mempengaruhi kehidupan lain. Menurut Ennis (1996:364), terdapat enam indikator dalam berpikir kritis yaitu: (1) Focus, untuk membuat sebuah keputusan tentang apa yang diyakini maka harus bisa memperjelas pertanyaan atau isu yang tersedia, yang coba diputuskan itu mengenai apa.(2) Reason, mengetahui alasan-alasan yang mendukung atau melawan putusan-putusan yang dibuat berdasar situasi dan fakta yang relevan. (3) Inference, mengidentifikasi asumsi dan mencari pemecahan, pertimbangan dari interpretasi akan situasi dan bukti. (4) Situation, memahami situasi dan selalu menjaga situasi dalam berpikir akan membantu memperjelas pertanyaan. (5) Clarity, menjelaskan arti atau istilah-istilah yang digunakan. (6) Overview, melangkah kembali dan meneliti secara menyeluruh keputusan yang diambil.

Menurut Slameto (2010:2), belajar adalah suatu usaha yang dilakukan seseorang untuk memperoleh suatu perubahan tingkah laku yang baru secara keseluruhan, sebagai hasil pengalamannya sendiri dalam interaksi dengan lingkungannya. Perubahan yang terjadi dalam 
belajar bersifat permanen, terjadi secara sadar, perubahan tersebut memiliki tujuan dan terarah. hasil belajar adalah suatu hasil yang diperoleh dari hasil tes yang dilakukan siswa setelah berakhirnya proses belajar mengajar yang bertujuan untuk mengetahui sudah sejauh mana kemajuan siswa tersebut. Hal itu diharapkan berwujud pada perubahan perilaku pada diri siswa tersebut. Perubahan tersebut dapat berupa: dari tidak tahu menjadi tahu, dari tidak bisa menjadi terampil. Tujuan secara umum adalah untuk memberikan penghargaan terhadap pencapaian belajar siswa dalam memperbaiki program kegiatan pembelajaran untuk meningkatkan kualitas siswa dan guru terhadap pencapaian kompetensi yang telah ditetapkan.

\section{METODE}

Jenis penelitian yang digunakan dalam penelitian ini adalah true eksperimental (eksperimen yang betul-betul), dengan desain penelitian pretest-posttest control group design. Variabel dalam penelitian ini adalah model pembelajaran inkuiri $(\mathrm{X})$, kemampuan berpikir kritis $\left(\mathrm{Y}_{1}\right)$ dan hasil belajar $\left(\mathrm{Y}_{2}\right)$.

Rancangan penelitian ini dimulai dengan melakukan pretest bagi kelompok eksperimen dan kelompok kontrol untuk mengetahui keadaan awal siswa. Selanjutnya pada kelas eksperimen pembelajaran dilakukan dengan menggunakan model pembelajaran inkuiri, sedangkan pada kelompok kontrol menggunakan bembelajaran konvensional. Kemudian dilakukan posttest bagi ke dua kelas. Subjek dalam penelitian ini adalah 20 siswa kelas IV SDN Tandes Kidul II/112 Surabaya sebagai kelas eksperimen dan 20 siswa kelas IV SDN Tandes Lor Surabaya sebagai kelas kontrol. Instrumen penelitian yang digunakan untuk mengumpulan data dalam adalah tes kemampuan berpikir kritis dan tes tes hasil belajar siswa.

Total skor kemampuan berpikir kritis siswa diukur dengan rumus:

$$
M=\frac{\sum f}{N} x 100
$$

Dengan :

$$
\begin{array}{ll}
\mathrm{M} & : \text { kemampuan berpikir kritis siswa } \\
\sum f & \text { : skor yang diperoleh siswa } \\
\mathrm{N} & \text { : skor maksimal }
\end{array}
$$

(Indarti, 2008: 25).

Kriteria penilaian kemampuan berpikir kritis sebagai berikut :

$$
\begin{aligned}
& 0-19=\text { Sangat Rendah } \\
& 20-39=\text { Rendah } \\
& 40-59=\text { Sedang }
\end{aligned}
$$

$$
\begin{gathered}
60-79=\text { Tinggi } \\
80-100=\text { Sangat Tinggi }
\end{gathered}
$$

Setelah diketahui nilai kemampuan berpikir kritis dan hasil belajar siswa, selanjutnya dilakukan uji asumsi analisis dengan uji normalitas dan uji homogenitas yang diolah dengan bantuan program SPSS 21.00. Selanjutnya setelah dilakukan uji normalitas dan uji homogenitas, dilakukan uji-t untuk mengukur pengaruh model pembelajaran inkuiri terhadap kemampuan berpikir kritis dan hasil belajar siswa.

\section{HASIL DAN PEMBAHASAN}

\section{A. Hasil Penelitian Kemampuan Berpikir Kritis}

Berdasarkan hasil penelitian diperoleh nilai signifikasi untuk hasil analisis normalitas kemampuan berpikir kritis pretest sebesar 0,881 di kelas eksperimen dan 1,084 di kelas kontrol. Untuk hasil analisis normalitas kemampuan berpikir kritis (posttest) sebesar 0,982 di kelas eksperimen dan 1,082 di kelas kontrol. Kedua kelompok pengujian tersebut memiliki nilai signifikasi > 0,05 maka dapat disimpulkan bahwa data kemampuan berpikir kritis pada masing-masing kelompok adalah berdistribusi normal. Sedangkan nilai homogenitas (pretest) sebesar 0,052 dan nilai homogenitas (posttest) sebesar 0,787 dengan angka signifikasi > 0,05 maka dapat disimpulkan bahwa varians sampel adalah homogen.

Sementara itu, nilai rata-rata kemampuan berpikir kritis pada pretest di kelas kontrol sebesar 43,5417 dan di kelas eksperimen sebesar 45,2083, kemudian dengan melihat hasil uji Independent sample T-test diperoleh diperoleh $\mathrm{t}_{\text {hitung }}=1,011<\mathrm{t}_{\text {tabel }}$ $=1,686$. Hasil sig. 2 tailed $0,318>\alpha(0,05){\text { maka } H_{o}}$ diterima dan $\mathrm{H}_{\mathrm{a}}$ ditolak. Hal ini menunjukkan bahwa tidak ada perbedaan kemampuan berpikir kritis siswa di kelas kontrol maupun eksperimen sebelum pemberian treatment.

Setelah diberikan perlakuan (treatment) dalam pembelajaran, dilakukan posttest pada kelas kontrol dan eksperimen dan diperoleh nilai rata-rata kemampuan berpikir kritis (posttest) pada kelas kontrol adalah 57,7083 dan kelas eksperimen adalah 91,2500. Kemudian dengan melihat hasil uji Independent Sample T test diperoleh $\mathrm{t}_{\text {hitung }}=13,539>$ $\mathrm{t}_{\text {tabel }}=1,686$. Sig. 2 tailed $0,000<0,05$ maka $\mathrm{H}_{\mathrm{o}}$ ditolak dan $\mathrm{H}_{\mathrm{a}}$ diterima. Hal ini menunjukkan bahwa ada perbedaan kemampuan berpikir kritis siswa di kelas kontrol dan kelas eksperimen setelah diberi perlakuan. 


\section{B. Hasil Penelitian Hasil Belajar}

Berdasarkan hasil penelitian diperoleh nilai uji normalitas (pretest) sebesar 0,564 di kelas eksperimen dan 0,618 di kelas kontrol, karena kedua kelompok pengujian tersebut memiliki nilai signifikasi $>0,05$ atau $>5 \%$ maka dapat disimpulkan bahwa data hasil belajar siswa pada masing-masing kelompok (pretest) adalah berdistribusi normal. Sementara itu, untuk hasil analisis normalitas hasil belajar (posttest) sebesar 0,517 di kelas eksperimen dan 1,178 di kelas kontrol. Kedua kelompok pengujian tersebut memiliki nilai signifikasi > 0,05 atau > 5\% maka dapat disimpulkan bahwa data hasil belajar siswa pada masing-masing kelompok adalah berdistribusi normal. Untuk uji homogenitas diperoleh nilai homogenitas (pretest) sebesar 0,683 dan homogenitas (posttest) sebesar 0,469 karena angka signifikasi > 0,05 maka dapat disimpulkan bahwa varians sampel adalah homogen.

Nilai rata-rata hasil belajar siswa pada pretest kontrol sebesar 69,75 dan di kelas eksperimen sebesar 70,50 , kemudian dengan melihat hasil uji Independent sample T test diperoleh diperoleh $\mathrm{t}_{\text {hitung }}=0,231<\mathrm{t}_{\text {tabel }}$ $=1,686$. Hasil sig. 2 tailed $0,819>\alpha(0,05)$ maka $\mathrm{H}_{\mathrm{o}}$ diterima dan $\mathrm{H}_{\mathrm{a}}$ ditolak. Hal ini menunjukkan bahwa tidak ada perbedaan hasil belajar siswa di kelas kontrol maupun eksperimen.

Setelah diberikan perlakuan (treatment) dalam pembelajaran, dilakukan posttest pada kedua kelas dan diperoleh nilai rata-rata hasil belajar pada kelas kontrol adalah 75,75 dan kelas eksperimen adalah 87,50 kemudian dengan melihat hasil uji Independent Sample T test pada tabel 4.19 Diperoleh $t_{\text {hitung }}=4,459$ $>\mathrm{t}_{\text {tabel }}=1,686$. Sig. 2 tailed $0,000<0,05$. Hal ini berarti bahwa $\mathrm{H}_{\mathrm{o}}$ ditolak dan $\mathrm{H}_{\mathrm{a}}$ diterima yang berarti ada perbedaan hasil belajar siswa di kelas kontrol dan kelas eksperimen. Padahal kemampuan awal siswa sebelum diberikan perlakuan tidak berbeda secara signifikan. Namun setelah diberi perlakuan menggunakan model pembelajaran inkuiri pada kelompok eksperimen, hasil belajarnya lebih baik dari pada kelompok kontrol yang diberikan perlakuan dengan metode konvensional. Sehingga hasil belajar siswa yang mengikuti pembelajaran dengan model inkuiri lebih baik dibandingkan yang mengikuti pembelajaran dengan metode konvensional.

\section{PENUTUP}

\section{Simpulan}

Berdasarkan diskusi hasil penelitian dapat disimpulkan bahwa model pembelajaran inkuiri mempunyai pengaruh terhadap kemampuan berpikir kritis siswa. Hal ini dapat dilihat dari hasil analisis diperoleh $\mathrm{t}_{\text {hitung }}=13,539$ dengan signifikasi 0,05 dan $\mathrm{df} 38$. Oleh karena itu, disimpulkan bahwa siswa mempunyai kemampuan berpikir kritis yang tinggi dalam belajar dengan menggunakan model pembelajaran inkuiri.

Model pembelajaran inkuiri mempunyai pengaruh terhadap hasil belajar siswa. Terbukti dengan hasil analisis yang menunjukkan bahwa $t_{\text {hitung }}=4,459$ dengan signifikasi 0,05 dan df 38. Oleh karena itu disimpulkan bahwa siswa memiliki hasil belajar yang baik dengan menggunakan model pembelajaran inkuiri

\section{Saran}

Berdasarkan hasil penelitian yang diperoleh, maka saran yang dapat diberikan oleh peneliti adalah:

1. Bagi guru, disarankan menggunakan model pembelajaran inkuiri sebagai salah satu alternatif dalam kegiatan pembelajaran, karena dapat meningkatkan kemampuan berpikir kritis dan hasil belajar siswa. Hal ini memungkinkan siswa belajar aktif di dalamnya untuk menemukan pemecahan masalah.

2. Penelitian ini hanya meneliti tentang pengaruh model pembelajaran inkuiri terhadap kemampuan berpikir kritis dan hasil belajar siswa, bagi peneliti yang ingin meneliti dengan variabel yang sama disarankan menggunakan materi atau tema yang berbeda sehingga kemampuan berpikir kritis dan hasil belajar dapat dilihat dari beberapa materi lain yang mempengaruhinya.

\section{DAFTAR PUSTAKA}

Abdi, Ali. (2014). The Effect of Inquiry-based Learning Method on Students' Academic Achievement in Science Course. Department of Educational Sciences Payame noor University . Universal Journal of Educational Research 2 (1): 37-41.

Aizikovist-Udi, Einav. (2011). Developing The Skills of Critical and Creative Thinking By Probability Teaching. Procedia Social and Behavioral Science 15, 1087-1091.

Akyus, Halil Ibrahim. (2009). The effects of blended learning environment on the critical thinking skills of student. Elsavier Ltd. All rights reseved Procedia Social and Behavioral Sciences, I, 1744-1748. 
Amri, Sofan dan Iif Khoiru Ahmadi. (2010). Proses Pembelajaran Kreatif dan Inovatif dalam kelas. Jakarta: Prestasi Pustaka

Amri, Sofan dan Iif Khoiru Ahmadi. (2014). Pengembangan dan Model Pembelajaran Tematik Integratif. Jakarta: Prestasi Pustaka

Anam, Khoirul. (2015). Pembelajaran Berbasis Inkuiri Metode dan Aplikasi. Yogyakarta: Pustaka Pelajar.

Anderson, Lorin W. dan David R. Krathwohl. (2011). A Taxonomyz for Learning, Teaching and Assesing. Yogyakarta: Pustaka Pelajar.

Anderson-Meger, Jennifer. (2011). Critical Thinking and E-Learning in Social Work Education. International Journal of Business, Humanities and Technology Vol. 1 No. 2.

Andrini, Septi Vera. (2016). The Effectivness of Inquiry Learning Method Enhance Student's Learning Outcome: A Theoritical and Empirical Review. Journal of Education and Practice. Vol. 7, No. 3 , pp 38-42.

Aqib, Zainal, dkk. (2009). Penelitian Tindakan Kelas untuk Guru SD, SLB, dan TK. Bandung: CV.Yrama Widya.

Arends, Richard I. (2011). Learning to teach ninth edition. Singapore: Mc Graw Hill.

Arikunto, Suharsimi. (2010). Prosedur Penelitian Suatu Pendekatan Praktik. Jakarta: Rineka Cipta.

Arikunto, Suharsimi. (2013). Dasar-dasar Evaluasi Pendidikan Edisi 2. Jakarta: Bumi Aksara.

Aunurrahman. (2014). Belajar dan Pembelajaran. Bandung: Alfabeta

Constantinos Manoli, Margus Pedaste, Mario M“aeots, Leo Siiman, Ton De Jong, et al. (2015). Phases of inquiry-based learning: definitions and the inquiry cycle. Educational Research Review, Elsevier. Vol. 14, pp. 47-461.

Darmawan, Deni. (2013). Metode Penelitian Kuantitatif. Bandung: PT Remaja Rosdakarya

Duron, Robert, Barbara Limbach, dan Wendy Waugh. (2006). Critical Thinking Framework For Any Discipline. International Journal of Teaching and Learning in Higher Education. Vol. 17, No. 2, pp 160-166

Facione. (1990). Critical Thinking: A Statement of Expert Consensus for Purposes of Educational Assesment and Intruction. California: Academic Press.
Fogarty, R. (1991). The Mindful School How To Integrate The Curricula. USA: IRI/Skylight publishing.

Hamruni. (2012). Strategi Pembelajaran. Yogyakarta: Insan Madani.

Ibrahim, M. (2011). Kurikulum dan Pembelajaran. Jakarta: PT. Rajagrafindo Persada.

Ibrahim, Muslimin dkk. (2011). Dasar-Dasar Proses Belajar Mengajar. Surabaya: Unesa University Press.

Indarti, Titik. (2008). Penelitian Tindakan Kelas (PTK) dan Penulisan Ilmiah. Surabaya: Lembaga Penerbit FBS Unesa.

Jacobsen, A. David dkk. (2009). Methods For Teaching. Yogyakarta: Pustaka Pelajar.

Jauhar, Mohammad. (2011). Implementasi Paikem dari Behavioristik sampai Konstruktivistik. Jakarta: Prestasi Pustakarya

Johnson, Elaine B. (2002). Contextual Teaching and Learning. London: Corwin Press Inc.

Joyce, Bruce and Marsha Weil. (1980). Models of Teaching. United State of America: Prentice Hall International Inc.

Kuhlthu, Carol C., Leslie K. Maniotes, Anna K. Caspari. (2007). Guided Inquiry Learning in the $21^{S T}$ Century. United State of America: Libraries Unlimited Inc.

Mustachfidoh, I. B Jelantik Swasta, N.L.P. Manik Widiyanti. (2013). Pengaruh Model Pembelajaran Inkuiri Terhadap Prestasi Belajar Biologi Ditinjau dari Intelegensi Siswa SMA Negeri 1 Srono. e-Journal Program Pascasarjana Universitas Pendidikan Ganesa. Volume 3, No. 1.

Purwoto, Agus. (2003). Panduan Laboratorium Statistik Inferensial. Jakarta: Gramedia Widiasarana Indonesia.

Ratumanan, Tanwey Gerson dan Theresia Laurens. (2011). Penilaian Hasil Belajar Pada Tingkat Satuan Pendidikan. Surabaya: Unesa University Press.

Riduwan dan Sunarto. (2009). Pengantar Statistika Untuk Penelitian Pendidikan, Sosial, Ekonomi, Komunikasi, dan Bisnis. Bandung: Alfabeta.

Riduwan. (2006). Metode dan teknik Penyusunan Tesis. Bandung: Alfabeta

Salim, K. \& Tiawa D.H. (2015). Implementation of Structured Inquiry Based Model Learning Toward Students' Understanding of Geometry. 
International Journal of Research in Education and Science (IJRES), Vol. 1 (1), pp. 75-83.

Sani, Ridwan Abdullah. (2014). Inovasi Pembelajaran. Jakarta: Bumi Aksara.

Sanjaya, Wina. (2009). Strategi Pembelajaran Berorientasi Standar Proses Pendidikan. Jakarta: Kencana Prenada Media Group.

Sayyadi, Muhammad, Arif Hidayat, Muhardjito. (2016). Pengaruh Strategi Pembelajaran Inkuiri Terbimbing Terhadap Kemampuan Pemecahan Masalah Fisika Pada Materi Suhu dan Kalor Dilihat Dari Kemampuan Awal Siswa. Jurnal Inspirasi Pendidikan Universitas Kanjuruan Malang. Vol. 6 No.2

Simbolon, Dedi Holden. (2015). Pengaruh Model Pembelajaran Inkuiri Terbimbing Berbasis Eksperimen Riil dan Laboraturium Virtual Terhadap Hasil Belajar Fisika Siswa. Jurnal Pendidikan dan Kebudayaan. Vol.21, Nomor 3

Slavin, Robert E. (2011). Psikologi Pendidikan Teori dan Praktik. Jakarta: Indeks

Smallhorn, M., Young, J., Hunter, N. \& Burke da Silva, K. (2015). Inquiry-based learning to improve student engagement in a large first year topic. Student Success, Vol. 6 (2), 65-71. doi: 10.5204/ssj.v6i2.292

Suaidy Haris, Sugeng Utaya , Budi Eko Soetjipto. (2016). The Enhancement of Process Skills and Cognitive Learning Outcomes of Science in Elementary School Through Inquiry Learning. IOSR Journal of Research \& Method in Education (IOSR-JRME). Vol. 6, Issue 3 Ver. III, pp 67-71

Subaryana. (2005). Pengembangan Bahan Ajar. Yogyakarta: IKIP PGRI Wates

Sudjana, Nana. (2009). Dasar- Dasar Proses Belajar Mengajar. Bandung: PT Sinar Baru Algensindo

Sudjana, Nana. (2011). Penilaian Hasil Proses Belajar Mengajar. Bandung: PT Remaja Rosdakarya.

Sugiyono. (2011). Metode Penelitian Kuantitatif Kualitatif dan $R \& D$. Bandung: Penerbit Alfabeta.

Sugiyono. (2012). Statistik Untuk penelitian. Bandung: Alfabeta.

Sukma, Laili Komariyah, Muliati Syam. (2016). Pengaruh Model Pembelajaran Inquiry Terbimbing dan Motivasi Terhadap Hasil Belajar Fisika Siswa. Saintifika, Jurusan PMIPA, FKIP, Universitas Jember. Vol. 18, No. 1, hlm. 59 - 63.
Surya, Hendra. (2011). Strategi Jitu Mencapai Kesuksesan Belajar. Jakarta: PT Elek Media Komputindo

Susanto, Sigit. (2015). Pengaruh Penerapan Pembelajaran Berbasis Masalah Terhadap Kemampuan Berpikir Kritis dan Pemahaman Siswa pada Materi Penjumlahan dan Pengurangan Bilangan Bulat di Kelas IV Sekolah Dasar. Surabaya: Tesis Program Pascasarjana Universitas Negeri Surabaya

Sutama, I Nyoman, Ida Bagus Putu Arnyana, Ida Bagus Jelantik Swasta. (2014). Pengaruh Model Pembelajaran Inkuiri Terhadap Keterampilan Berpikir Kritis dan Kinerja Ilmiah Pada Pelajaran Biologi Kelas XI IPA SMA Negeri 2 Amplapura. e-Journal Program Pascasarjana Universitas Pendidikan Ganesha, Vol. 4

Sutarto, Damris M., Khairinal. (2011). Pengaruh Metode Inkuiri dan Motivasi Belajar Terhadap Hasil Belajar Listrik Statis Dalam Pembelajaran IPA. Tekno-Pedagogi. Vol. 1, No. 1, pp 33-39

Sutrisno, Tri. (2015). Pengaruh Pembelajaran Berbasis Masalah (Problem Based Learning) Terhadap Kemampuan Berpikir Kritis Siswa Pada Mata Pelajaran PKn Kelas VI di SDN Kota Sumenep. Surabaya: Tesis Program Pascasarjana Universitas Negeri Surabaya.

Thompson, Claudette. (2011). Critical Thinking Across The Curiculum: Process Over Output. International Journal of Humanities and Social Science. Vol 1, No. 9

Trianto. (2010). Model-Model Pembelajaran Inovatif Berorientasi Konstruktivistik. Jakarta: Prestasi Pustaka.

Uswatun, Din Azwar, Eli Rohaeti. (2015). Perangkat Pembelajaran IPA Berbasis Inkuiri Untuk Meningkatkan Critical Thinking Skills dan Scientific Attitude Siswa. Journal Inovasi Pendidikan IPA. Vol. 1, No. 2, pp 138-152.

Warsono. (2012). Pembelajaran Aktif. Bandung: Remaja Rosdakarya.

Winarsunu, Tulus. (2009). Statistik dalam Penelitian Psikologi dan Pendidikan. Malang: UMM Press. 